ORIGINAL ARTICLE

\title{
Assessing the construct validity and reliability of the Academic Motivation Scale in the Vietnamese context
}

\author{
Quang Ngoc Nguyen ${ }^{A, B, C, D, E, F}$, Luot Van Nguyen ${ }^{A, D, E, F, G}$ \\ University of Social Sciences and Humanities, Vietnam National University, Hanoi, Vietnam
}

BACKGROUND

Academic motivation is one of the most studied constructs in psychology. However, in Vietnam, the lack of valid and reliable instruments evaluating academic motivation has led to limitations in research on this topic. The Academic Motivation Scale (AMS) is widely applied to different contexts across the world. The purpose of the study is to assess the construct validity and reliability of the AMS with a sample of Vietnamese university students.

\section{PARTICIPANTS AND PROCEDURE}

The research study was conducted with a convenience sample of 341 university students. Male students accounted for $11.70 \%$ of participants. The average age was 20.28 with a standard deviation of 1.12. To participate in the study, students conducted an online questionnaire consisting of the AMS. We conducted confirmatory factor analysis (CFA) and correlation analysis and calculated Cronbach's $\alpha$ to examine the validity and reliability of the scale.
RESULTS

CFA indicated that the seven-factor model fitted the data best, with all the unstandardized factor loadings being statistically significant. Regarding reliability, AMS subscales had satisfactory Cronbach $\alpha$ s. Correlation analysis supported almost entirely the hypothesis about simplex structure of the AMS.

\section{CONCLUSIONS}

Considering the results, we suggest that the AMS has met the requirements for validity and reliability, and could be used in research with Vietnamese university students on academic motivation itself and its relationships with other psychological constructs.

\section{KEY WORDS}

reliability; self-determination theory; construct validity; simplex structure; academic motivation scale 


\section{BACKGROUND}

In the field of psychology and education, academic motivation is an important psychological construct and has been extensively studied by many authors (Anderman \& Dawson, 2013). Based on the general concept of motivation (Reeve, 2009), it is possible to define academic motivation as factors or processes that influence the beginning, direction, intensity, and persistence of behaviours related to knowledge acquisition and achievement in learning environments. Academic motivation not only affects students' performance (De Feyter, Caers, Vigna, \& Berings, 2012; Everaert, Opdecam, \& Maussen, 2017; Green et al., 2012; Kusurkar, Ten Cate, Vos, Westers, \& Croiset, 2013), but is also interrelated to a wide range of issues such as their adaptation to college (Beyers \& Goossens, 2002; Conti, 2000), dropout status (Alivernini \& Lucidi, 2011; Rump, Esdar, \& Wild, 2017), persistence (Ratelle, Guay, Vallerand, Larose, \& Senécal, 2007; Renaud-Dubé, Guay, Talbot, Taylor, \& Koestner, 2015), procrastination (Cavusoglu \& Karatas, 2015; Klassen \& Kuzucu, 2009; Lee, 2005), coping with academic stress (Bonneville-Roussy, Evans, Verner-Filion, Vallerand, \& Bouffard, 2017; Struthers, Perry, \& Menec, 2000; Thompson \& Gaudreau, 2008), the capacity to use effective learning strategies (Donche, De Maeyer, Coertjens, Van Daal, \& Van Petegem, 2013; Liu et al., 2014), or psychological problems that students often encounter such as stress (Baker, 2004; Liu, 2015; Struthers et al., 2000), depression (Elmelid et al., 2015; Miller \& Markman, 2007), and anxiety (Bullard, 2016; Khalaila, 2015; Lavasani, Weisani, \& Ejei, 2011). Therefore, research studies on the status, causes, and interventions for these issues could not ignore academic motivation. In Vietnam, academic motivation is a crucial topic and has been studied by many educators and psychologists (Bui, 2009, 2011, 2017; Duong, 2008, 2013). Nevertheless, an issue that remains in the study of this topic in Vietnam is the lack of validated and reliable instruments evaluating academic motivation. This condition has led to numerous limitations on the quality of research as well as the ability to compare results between domestic and foreign studies.

The Academic Motivation Scale (AMS) developed by Vallerand et al. (1992) is an instrument that has been widely used in many studies on academic motivation around the world. In Vietnam, it was introduced by Bui (2011) and has been adopted in a number of studies (Bui, 2009, 2017). However, it has not been adapted and validated. The aim of the present study is to assess the construct validity and reliability of the AMS in the Vietnamese context, thereby providing an academic motivation measurement tool that assures psychometric properties for future studies on this topic with Vietnamese samples.

\section{SELF-DETERMINATION THEORY OF ACADEMIC MOTIVATION}

For nearly 50 years, the attempt to improve students' academic performance as well as to resolve their problems related to academic activities has led to an enormous number of research studies on academic motivation (Anderman \& Dawson, 2013). Many theories of motivation have been developed to underpin these studies (Reeve, 2009). Self-determination theory (SDT) by Deci and Ryan (1985c) is one of the most widely applied theories.

SDT argues that humans have two primary types of motivation (Deci \& Ryan, 1985b). They are intrinsic and extrinsic motivation. The manifestation of intrinsic motivation is that an individual performs an activity because the activity itself is attractive to the individual, and as a result, he or she enjoys inward rewards such as joy and satisfaction occurring while performing the activity. For example, an intrinsically motivated student asked for the reasons why he or she goes to university is likely to answer that he or she wants to experience the fascination and the excitement of studying and discussing the subjects in which he or she is interested. In contrast, an extrinsically motivated student participates in an activity in the hope of achieving the results that only appear after the activity has completed. For instance, a majority of students go to university because they want to earn a degree, which facilitates their job seeking, instead of being really interested in acquiring knowledge and/or expanding their understanding.

From the point of view of SDT, the nature of intrinsic motivation is inherent human growth tendencies (Deci \& Ryan, 1985a). These tendencies motivate individuals to actively engage in undertakings and interact with environmental stimuli in order to explore and enhance their capacity and knowledge. This continuous process helps people achieve physiological, psychological, and social development. Meanwhile, the origin of extrinsic motivation is external forces, including values, expectations, norms, and requirements that come from society, family, school, teachers, friends and colleagues, etc.

The reason why individuals behave according to the regulation of external forces is that they are always eager to satisfy three basic psychological needs - for relatedness, for competency, and for autonomy (Deci \& Ryan, 1985b). The deficiency in fulfilment of basic psychological needs causes individuals to accept external forces governing their behaviour. On the other hand, when these basic psychological needs are satisfied, the intrinsic motivation of individuals will be maintained and promoted, and/or internalization, which is the process through which individuals receive, accept, and assimilate external adjustments to their self-construct, will occur more promptly, leading to higher levels of autonomy. 
Based on the degree of autonomy in extrinsically motivated individuals' behaviours, Deci and Ryan (1985d) divided extrinsic motivation into four types, namely, external regulation (ER), introjected regulation (INR), identified regulation (IDR), and integrated regulation (ITR).

ER is a type of motivation that has the lowest level of autonomy and internalization. An ER motivated individual engages in an activity just in order to satisfy a request from outside. By this way, they can receive a reward or avoid a punishment. For example, students do exam revision in order to gain a good mark, or solely to avoid a bad result.

With INR, individuals receive and accept partly external adjustments, manifesting in the feeling of guilt or anxiety that they have to experience when they are not carrying out the activity. Individuals perform activities only to avoid negative feelings and to protect their self or to increase their self-esteem. For example, students go to college merely to protect their family's honour or to gain respect from others because their socio-cultural environment places great importance on college.

At a higher level of autonomy, which means the process of internalization is more thorough, individuals accept the values, expectations, norms of the society or the external adjustment, thereby evaluating that activity plays an important role for themselves and deciding to carry out the activity. The fact that a student takes English studies as a second major because he or she believes English is a good source of support for future work is an example of the identified relegation.

With ITR, individuals not only recognize the importance of activity, but also integrate this assessment into the aspects of their self-construct or assimilate external values, expectations, and norms. Considering the situation above, integrated regulated students not only assume that English is important for the job, but also believe that English is a compulsory skill that everyone must have in a modern working environment.

In addition, Deci and Ryan (1985b) introduced the concept of amotivation (AM) to indicate the situation in which individuals do not act or act inactively and superficially, because they believe that they lack the capacity or they think the activity cannot bring the values that they need. For example, some students might feel that they are not benefiting from college or are wasting their time in college because they have had a small business with a stable income.

\section{ACADEMIC MOTIVATION SCALE}

As mentioned, the AMS is a measurement tool commonly used in studies on academic motivation. The AMS was developed based on SDT by Vallerand et al.
(1992) and consists of 28 items divided into seven subscales that are used to measure seven types of academic motivation: AM, ER, INR, IDR, intrinsic motivation to know (IMTK), intrinsic motivation toward accomplishments (IMTA), and intrinsic motivation to experience stimulation (IMTE). Participants are required to rate the accuracy of 28 items corresponding to 28 answers to the question "Why do you go to university?" on a 7-point Likert scale from 1 (does not correspond at all) to 7 (corresponds exactly).

It is should be noted that the division of intrinsic motivation into three different types reflects the fact that individuals are motivated by different reasons rather than the variances in the degree of autonomy among these motivations. With IMTK, individuals undertake learning activities for the joy and satisfaction gained during the exploration of new or unknown things. With IMTA, individuals perform learning activities because they like the feeling of joy and satisfaction when they try to surpass themselves and attain new achievements. Meanwhile, individuals who study with IMTE expect to have new experiences and feelings while learning.

According to Vallerand et al. (1992), empirical data as well as the results of factor analysis in many studies have shown that university students do not have ITR in the structure of academic motivation. The researchers argued that the results might come from a number of factors, especially the age factor. In particular, students are not old enough to be able to integrate learning into their self-construct or consider it as a value for themselves. Supporting this view, the recent research findings of Burgueño, Sicilia, MedinaCasaubon, Alcaraz-Ibañez, and Lirola (2017) showed that ITR was in the structure of academic motivation of graduate pedagogy students who have matured and had a clear career orientation. However, some authors have suggested that further research into this type of motivation should be conducted in a wide range of samples (Fairchild, Horst, Finney, \& Barron, 2005).

\section{PREVIOUS STUDIES ON ADAPTATION AND VALIDATION OF THE AMS}

The AMS has been adapted and validated with diverse samples in different cultural contexts including Canada (Grouzet, Otis, \& Pelletier, 2006; Guay, Morin, Litalien, Valois, \& Vallerand, 2015; Vallerand, Blais, Brière, \& Pelletier, 1989; Vallerand et al., 1992, 1993), the United States (Cokley, 2000, 2015; Cokley, Bernard, Cunningham, \& Motoike, 2001; Fairchild et al., 2005; Liu, Ferrell, Barbera, \& Lewis, 2017; Osei Akoto, 2014; Smith, Davy, \& Rosenberg, 2010, 2012), Brazil (Davoglio, Santos, \& Lettnin, 2016; Stover, de la Iglesia, Boubeta, \& Liporace, 2012), Chile (Orsini et al., 2015), Poland (Ardeńska et al., 2016), Hungary (Tóth-Király et al., 2017), Greece (Barkoukis, 
Tsorbatzoudis, Grouios, \& Sideridis, 2008; Tsorbatzoudis, Barkoykis, \& Grouios, 2001), Norway (Støen Utvær \& Haugan, 2016), France (Tóth-Király et al., 2017), Spain (Burgueño et al., 2017), Slovenia (Puklek Levpušček \& Podlesek, 2017), Turkey (Ardeńska et al., 2016; Aydin, Yerdelen, Gürbüzoğlu Yalmanci, \& Göksu, 2014; Can, 2015; Cavusoglu \& Karatas, 2015; Haslofça \& Korkmaz, 2016; Karaguven, 2012) and Italy (Alivernini \& Lucidi, 2008). Specially, the AMS was also adapted with Asian samples in Malaysia (Chong \& Ahmed, 2012), Singapore (Caleon et al., 2015; Lim \& Chapman, 2015), and China (Zhang, Li, Li, Li, \& Zhang, 2016).

In the field of psychometry, adaptation and validation of a measurement instrument includes translation and examination of validity and reliability (Borsa, Damásio, \& Bandeira, 2012). In order to translate the AMS, some studies adopted the back translation or parallel back translation method, then evaluated the translations, selected the appropriate items, and conducted a pilot study to evaluate initially the scale's psychometric properties as well as to adjust the contents of items as needed (Alivernini \& Lucidi, 2008; Can, 2015; Karaguven, 2012; Stover et al., 2012). In terms of the validity, studies generally examine construct validity (factorial validity, simplex structure, and convergence and discriminant validity) and criterion validity (concurrent and predictive validity). Referring to the reliability of the AMS, the internal and temporal consistency of the subscales are the two indicators most often considered by researchers.

\section{Factorial validity}

In general, the factorial validity of the AMS is generally assessed by either confirmatory factor analysis (CFA) or exploratory factor analysis (EFA). Other studies also use principal component analysis (PCA) or exploratory structural equation modelling (ESEM) to determine the AMS factorial structure. The majority of the CFA results of the studies confirm the seven-factor structure that Vallerand et al. (1992) suggested (Barkoukis et al., 2008; Caleon et al., 2015; Guay et al., 2015; Haslofça \& Korkmaz, 2016; Liu et al., 2017; Orsini et al., 2015; Osei Akoto, 2014; Puklek Levpušček \& Podlesek, 2017; Smith et al., 2010; Zhang et al., 2016). However, several studies required additional residual correlations to improve the goodness-of-fit between empirical data and the theoretical seven-factor structure (Chong \& Ahmed, 2012; Liu et al., 2017; Vallerand et al., 1992, 1993). Given this issue, Fairchild et al. (2005) argued that, technically, adding residual correlations would inevitably change the original theoretical structure. Liu et al. (2017) commented that these residual relationships might result from the construction of items with similar words, patterns, and contents, or from the process of responding to them in which nearby items were being frequently rated with an identical score. However, the study of Fairchild et al. (2005), along with a number of further studies conducted with diverse samples, suggested that adding residual correlations is not necessary to confirm the sevenfactor structure.

Besides the seven-factor structure, the CFA results of some studies confirmed the five-factor structure corresponding to SDT (Can, 2015; Liu et al., 2017; Stover et al., 2012; Tóth-Király et al., 2017). This structure consisted of AM, ER, INR, IDR and intrinsic motivation that includes items from IMTK, IMTA, IMTE. Except for the study of Tóth-Király et al. (2017), the other studies that were carried out with samples of university students concluded that although the five-factor structure was consistent with the empirical data, its fit indices were lower than those of the seven-factor structure were. In contrast, the study of Tóth-Király et al. (2017) conducted with a sample of Hungarian high school students showed that the five-factor model corresponded to empirical data more closely than the seven-factor model. The researchers believed that, compared with university students, the age factor, and the different forms of education might be the reasons for the ambiguous distinction between the three types of intrinsic motivation in high school students. This comment was supported by the study of Lim and Chapman (2015), which was carried out in a group of Singaporean high school students.

Some studies using PCA or EFA in combination with CFA have found different structures. For example, the study of Cokley (2015) showed that all the seven-factor, five-factor, and three-factor structures were unfit for a sample of black students in the United States. Instead, the results of the EFA and CFA of this study explored a six-factor structure that, according to the authors, was difficult to explain in theory. The study of Smith et al. (2012) with a sample of US students, using EFA and CFA, also ended up with a new factorial structure for the AMS that included four factors (AM, ER, IDR, and intrinsic motivation) with 18 items. Noticeably, some items loaded on subscales in a way not consistent with the original hypothesis proposed by Vallerand et al. (1992). Using the same analytical method, the study of Aydin et al. (2014) with a sample of Turkish students devised another structure consisting of 19 items with four factors (AM, extrinsic motivation-career, extrinsic motivation-social, and intrinsic motivation). A four-factor structure with 21 items was found by EFA and CFA with two samples of Polish and Turkish students in the study of Ardeńska et al. (2016). The study of Lim and Chapman (2015) conducted upon a sample of Singaporean students explored a four-factor structure (AM, ER and IDR, INR, and intrinsic motivation). The commonality between these results is that the items of ER and IDR repeatedly load on the same factor. The same situa- 
tion also applies to the items of two pairs of subscales (INR and IMTA, and IMTK and IMTE).

From the previous findings mentioned above, it is obvious that although the seven-factor structure is adaptable to various groups of participant from different contexts, including Singapore, Malaysia, and China, there are still groups of participants and contexts in which that factorial structure is inappropriate. The researchers argue that, apart from differences in the characteristics of samples, such as age, education level, socioeconomic environment, culture, and education system, the inconsistency between research results also raises questions about the use of words and the composition of the items. These results and inquiries require additional studies to assess the AMS's psychometric properties in diverse samples as well as to find new fitting factorial structures by conducting EFA, CFA, and ESEM (Can, 2015; Cokley, 2015; Zhang et al., 2016).

\section{Complex structure}

Besides the factorial validity, Vallerand et al. (1993) also proposed a way of assessing the construct validity of the AMS that examines the correlation matrix between the subscales of the AMS. The researchers hypothesized that the correlation matrix would reflect the simplex structure of the AMS, consistent with the order of types of motivation arranged according to the degree of autonomy on the motivation spectrum proposed by SDT (Deci \& Ryan, 1985c). Specifically, the adjacent subscales on the motivation spectrum have stronger correlations than subscales farther apart (e.g., ER has a stronger positive correlation with INR than with IDR), and the subscales located on either end of the motivation spectrum should be negatively correlated (e.g., AM and intrinsic motivation subscales have a negative correlation). According to Fairchild et al. (2005), this kind of hypothesis is often used in evaluating the construct validity of scales built based on SDT. The results of previous studies do not fully confirm this hypothesis. Commonly observed deviations from the simplex structure are found in two subscales: INR and IDR (Barkoukis et al., 2008; Burgueño et al., 2017; Caleon et al., 2015; Can, 2015; Cokley, 2000, 2015; Fairchild et al., 2005; Guay et al., 2015; Lim \& Chapman, 2015; Orsini et al., 2015; Osei Akoto, 2014; Smith et al., 2010, 2012; Vallerand et al., 1992, 1993; Zhang et al., 2016). Specifically, many authors argue that INR has several similarities to intrinsic motivation, or in other words, a higher level of autonomy than IDR, contradicting the original hypothesis (Fairchild et al., 2005).

\section{Reliability}

For the reliability of the AMS, the two most frequently cited indicators in examining the reliability of the AMS are internal and temporal consistency. The
Cronbach $\alpha$ coefficients of AMS's subscales in virtually every study ranged from .70 to .85 , showing that the scale has adequate reliability. It should be noted that IDR usually had the smallest $\alpha$. This result raises the question of consistency in the content and words between the items of this subscale. In contrast, AM and IMTK were usually two subscales that had the highest degree of internal consistency. Researchers also conducted test-retest analyses to evaluate temporal consistency. The test-retest correlation coefficients were generally between .70 and .85 , indicating a good level of consistency between the two AMS measurements.

In summary, the literature review shows that AMS is an instrument that is widely used for a wide range of samples in many different countries. Most research results confirm the validity and reliability of the AMS with a seven-factor structure. However, a number of issues related to culture as well as the use of words and the composition of the items have led to different outcomes in EFA and PCA for different groups of participants. The hypothesis of the simplex pattern of the AMS was merely partially confirmed. This would require researchers who adapt and validate the AMS for a new context in the future to be careful with the translation process as well as to consider rewriting items for cultural suitability, and to clarify the differences between the subscales.

\section{RESEARCH AIM}

The present study examines the construct validity and reliability of the AMS in the context of Vietnam with the following specific objectives: (1) to assess the factorial validity of seven-, five-, and three-factor structure of the AMS; (2) to examine the reliability of each subscale of the best-fit factorial structure; and (3) to test the hypothesis of simplex structure of the AMS.

\section{PARTICIPANTS AND PROCEDURE}

\section{PARTICIPANTS}

The research study was conducted with a convenience sample of 341 university students. Women accounted for $88.30 \%$ and men accounted for $11.70 \%$ of participants. The average age was 20.28 with a standard deviation of 1.12 .

\section{PROCEDURE}

Students were invited to participate in the research via email. To participate in the study, students conducted an online questionnaire consisting of the AMS and some questions about gender, age, year of study, and department. Students participated in the study voluntarily, and were not paid. 


\section{MEASURES}

Due to limited resources, the authors only translated the AMS from English into Vietnamese. The initial translation was piloted on a group of participants including 90 college students. The Cronbach $\alpha$ coefficients of subscales range from .80 to .87 . IDR and IMTE have the lowest $\alpha$ s and the ER has the highest one. Based on the results of calculating $\alpha$ after the removal of each item in every subscale, the authors adjusted some of the words in items 2 and 12 to enhance the degree of similarity between these two items and the other items in the same subscale with them. As these removals did not show any significant improvement in the value of Cronbach's $\alpha$, we kept the 28 -item version.

The Vietnamese version of the AMS was used to assess participants' academic motivation. The scale consists of 28 items, divided into seven fouritem subscales. Students were asked to rate the accuracy of the items that correspond to the answers to the question "Why do you go to university?" on a 7-point Likert scale from 1 (does not correspond at all) to 7 (corresponds exactly).

\section{STATISTICAL ANALYSIS}

Quantitative data were evaluated through statistical calculations. To examine the factorial validity of the structures, the study conducted CFA with STATA 14.2. The theoretical models evaluated in this study include the seven-factor model proposed by Vallerand et al. (1992), the five-factor model based on SDT by Deci and Ryan (1985c), and the three-factor model including AM, extrinsic motivation, and intrinsic motivation. The factors were allowed to correlate while the residual variances of the items were not allowed to.

In CFA, the two most commonly used estimation methods are maximum likelihood (ML) and generalized least squares (GLS; Brown, 2015). However, both of them require normally distributed data (Brown, 2015). The analysis of multivariate normal distribution through kurtosis (1905.29) and skewness (169.20) according to Mardia's method showed that the data do not have normal distribution (Cain, Zhang, \& Yuan, 2017). Therefore, the study chose the robust maximum likelihood (robust ML) method for conducting CFA. According to Brown (2015), robust ML is a good estimation method for non-normally distributed data. Specifically, in this study, the MLM, one of the two forms of the robust ML, provides the Satorra-Bentler chi squared value $\left(\mathrm{SB} \chi^{2}\right)$. In addition, root mean square error of approximation (RMSEA), standardized root mean square residual (SRMR), comparative fit index (CFI) and Tucker-Lewis index (TLI) were also adjusted under the effect of non-normally distributed data by this estimation method.

Among the goodness-of-fit indices above, $\mathrm{SB} \chi^{2}$ represents the absolute fit of the model. However, this value is usually sensitive to the sample size. Specifically, the larger the sample size is, the greater is the degree of fit of the model (Brown, 2015). Therefore, besides the value of $\mathrm{SB} \chi^{2}$, we also considered other indices. In this study, we used four additional indices: RMSEA, SRMR, CFI and TLI. According to $\mathrm{Hu}$ and Bentler (1999), RMSEA values less than .06 and SRMR values less than .08 indicate good model fit. Whereas CFI and TLI values that range from .90 to 1.00 suggest adequate fit (Bentler, 1990).

The study also used STATA software to calculate means, to measure internal consistency of the AMS through Cronbach's $\alpha$, and to analyse the correlation between AMS subscales.

\section{RESULTS}

\section{FACTORIAL VALIDITY}

The goodness-of-fit statistics of the three models calculated by CFA are represented in Table 1. Five-factor and three-factor models had goodness-of-fit indices that did not meet the suggested criteria. In contrast, the value of the goodness-of-fit indices showed that the seven-factor model fit the empirical data $(\mathrm{CFI}=.921, \mathrm{TLI}=.910, \mathrm{SRMR}=.074)$. In addition, the $\mathrm{SB} \chi^{2}$ value (683.160) and the RMSEA value (.056) of the seven-factor model were also the smallest among

Table 1

Goodness-of-fit indices of the AMS's theoretical factorial models

\begin{tabular}{lcccccc}
\hline Scale & $\mathrm{SB} \chi^{2}$ & $d f$ & Robust RMSEA & Robust SRMR & Robust CFI & Robust TLI \\
\hline Seven-factor & 683.160 & 329 & .056 & .074 & .921 & .910 \\
Five-factor & 972.475 & 340 & .090 & .074 & .860 & .844 \\
Thee-factor & 1330.377 & 347 & .091 & .106 & .782 & .762 \\
\hline
\end{tabular}

Note. RMSEA - root mean squared error of approximation; SRMR - standardized root mean square residual; CFI - comparative fit index; TLI - Tucker-Lewis index. 
the models. All the unstandardized factor loadings were statistically significant $(p<.001)$. As shown in Table 2, standardized factor loadings ranged from .46 to .87 . The squares of these values produce the variance of items explained by the correspondent factors. They ranged from .21 to .76 .

As the standardized factor loading of item 1 was only .46, the study conducted CFA with the seven- factor model after removing this item. The results showed that the model was improved, but not significantly. Specifically, CFI $=.924$, TLI $=.912$, $\mathrm{SB} \chi^{2}=636.734$, RMSEA $=.057$ (slightly increased compared with the original model), and SRMR $=.046$. Since the removal of item 1 did not significantly improve the model, we decided to retain the seven-factor structure with the original 28 items.

Table 2

Standardized factor loadings of items calculated by CFA with seven-factor model of the AMS

\begin{tabular}{|c|c|c|c|c|c|c|c|}
\hline Item no. & $\mathrm{AM}$ & ER & INR & IDR & IMTK & IMTA & IMTE \\
\hline 26 & .87 & & & & & & \\
\hline 05 & .79 & & & & & & \\
\hline 19 & .78 & & & & & & \\
\hline 12 & .73 & & & & & & \\
\hline 22 & & .85 & & & & & \\
\hline 08 & & .84 & & & & & \\
\hline 15 & & .79 & & & & & \\
\hline 01 & & .46 & & & & & \\
\hline 28 & & & .82 & & & & \\
\hline 21 & & & .75 & & & & \\
\hline 14 & & & .71 & & & & \\
\hline 07 & & & .70 & & & & \\
\hline 17 & & & & .82 & & & \\
\hline 24 & & & & .69 & & & \\
\hline 10 & & & & .68 & & & \\
\hline 03 & & & & .66 & & & \\
\hline 16 & & & & & .86 & & \\
\hline 23 & & & & & .84 & & \\
\hline 09 & & & & & .76 & & \\
\hline 02 & & & & & .66 & & \\
\hline 13 & & & & & & .83 & \\
\hline 27 & & & & & & .80 & \\
\hline 06 & & & & & & .77 & \\
\hline 20 & & & & & & .69 & \\
\hline 25 & & & & & & & .81 \\
\hline 18 & & & & & & & .81 \\
\hline 11 & & & & & & & .74 \\
\hline 04 & & & & & & & .66 \\
\hline
\end{tabular}

Note. AM - amotivation; ER - external regulation; INR - introjected regulation; IDR - identified regulation; IMTK - intrinsic motivation to know; IMTA - intrinsic motivation toward accomplishment; IMTE - intrinsic motivation to experience stimulation. All the unstandardized factor loadings were statistically significant $(p<.001)$. 
Quang Ngoc Nguyen, Luot Van Nguyen

Table 3

Correlation coefficients, means, standard deviations and Cronbach $\alpha$ s of AMS subscales

\begin{tabular}{|c|c|c|c|c|c|c|c|}
\hline & $\mathrm{AM}$ & ER & INR & IDR & IMTK & IMTA & IMTE \\
\hline AM & $(.87)$ & -.07 & -.20 & -.53 & -.58 & -.33 & -.47 \\
\hline ER & & $(.81)$ & .74 & .68 & .27 & .47 & .26 \\
\hline INR & & & $(.83)$ & .68 & .51 & .83 & .52 \\
\hline IDR & & & & $(.80)$ & .79 & .68 & .72 \\
\hline IMTK & & & & & $(.86)$ & .71 & .97 \\
\hline IMTA & & & & & & $(.86)$ & .74 \\
\hline IMTE & & & & & & & $(.85)$ \\
\hline Mean & 11.40 & 18.90 & 17.61 & 20.40 & 20.45 & 16.86 & 18.45 \\
\hline SD & 4.91 & 4.54 & 4.51 & 3.90 & 4.08 & 4.43 & 4.25 \\
\hline
\end{tabular}

Note. AM - amotivation; ER - external regulation; INR - introjected regulation; IDR - identified regulation; IMTK - intrinsic motivation to know; IMTA - intrinsic motivation toward accomplishment; IMTE - intrinsic motivation to experience stimulation. SD - standard deviation. Except for the correlations between AM and ER $(p>.05)$ and between AM and INR $(p<.05)$, the other correlations are statistically significant at $p<.001$. Values in parentheses are Cronbach $\alpha$ s.

\section{RELIABILITY}

With a seven-factor structure of 28 items, the study assessed subscales' internal consistency through Cronbach's $\alpha$. The results presented in Table 3 showed that the AMS subscales had adequate internal consistency with $\alpha$ values of .80 to .86 . As regards ER, similar to the observation from CFA, the Cronbach $\alpha$ analysis showed that removing item 1 would improve the subscale's internal consistency with a new $\alpha$ of .86, compared with the previous value of .81 .

\section{SIMPLEX STRUCTURE}

Table 3 presents the correlation matrix between AMS subscales calculated by CFA to minimize the measurement error. The results showed the magnitude of the correlations between ER and the other subscales decreased in order from INR $(r=.74)$, IDR $(r=.68)$ to intrinsic motivation subscales $(r=.27, .47, .26)$.

The correlations between INR and the other subscales also reflected the same pattern. It can be seen, however, that the correlation between INR and IMTA $(r=.83)$ was greater than those between INR and the remaining intrinsic motivation subscales $(r=.51, .52)$.

The results showed that the correlations between IDR and IMTK $(r=.79)$, and IMTE $(r=.72)$ were stronger than the correlation between INR and these subscales $(r=.51, .52)$. However, the correlation between INR and IMTA $(r=.83)$ was greater than the one between IDR and IMTA $(r=.68)$. The correlations between IDR and external motivation subscales $(r=.68, .68)$ was not significantly different from the correlation between IDR and intrinsic motivation subscales $(r=.79, .68, .72)$. Furthermore, AM correlated with IDR $(r=-.53)$ more strongly than with IMTA $(r=-.33)$ and with IMTE $(r=-.47)$, and as approximately strongly as with IMTK $(r=-.58)$.

The correlations between intrinsic motivation forms were quite strong $(r=.71, .97, .74)$. Especially, the correlation between IMTK and IMTE was very strong $(r=.97)$. The correlations between the intrinsic motivation subscales and the extrinsic motivation subscales were moderate or strong, ranging from .26 to .79. The reader can find the AMS Vietnamese version in the Appendix.

\section{DISCUSSION}

Due to the lack of instruments assessing academic motivation in the field of education and psychology in Vietnam, the present study was conducted to examines the construct validity and reliability of the AMS in the context of Vietnam with the following specific objectives: (1) to assess the factorial validity of seven-, five-, and three-factor structure of the AMS; (2) to examine the reliability of each subscale of the best-fit factorial structure; and (3) to test the hypothesis of simplex structure of the AMS.

The CFA results showed that the seven-factor model was the best-fitting model with all items loaded on factors consistently with the hypothesis. As the fiveand three-factor models did not meet the suggested criteria, showing they did not fit the empirical data, these results demonstrated that academic motivation is a multidimensional construct with seven different types of motivation instead of five or three dimensions, in the context of Vietnam. Thus, studies on the aca- 
demic motivation of Vietnamese students need to consider the relationship between these types of motivation instead of considering it as a unilateral structure.

As item 1 had the lowest standardized factor loading, we conducted the seven-factor model without the item. The model was improved but not significantly. In addition, the Cronbach $\alpha$ analysis showed that removing item 1 would slightly improve the ER subscale's internal consistency. That item 1 "Because with only a high-school diploma I would not find a high-paying job later on" has the lowest standardized factor loading also appeared in a study with a sample of Brazilian students conducted by Stover et al. (2012). These outcomes might result from the fact that item 1 was constructed in the negative orientation while the rest of the subscale's items had a positive structure. Moreover, respondents could rate this item according to social conception rather than to their own circumstances. Specifically, in Vietnam, the society tends to overemphasize the university degree (Le, 2016). There is a conception that people can only have a good job if they have a university degree (Dao, 2008; Nguyen, 2017). However, since the removal of item 1 did not significantly improve the model, we decided to retain the seven-factor structure with the original 28 items. Studies in the future might have to consider refining this item.

Regarding the reliability, Cronbach's $\alpha$ analysis showed that AMS subscales had adequate internal consistency. These results were higher than those of previous studies, indicating that AMS is reliable with the sample of Vietnamese university students.

Correlation analysis supported almost entirely the hypothesis about simplex structure of the AMS. Specifically, the results showed that the correlations between ER and the other subscales reflect a simplex structure. The magnitude of the correlations decreased in order from INR, IDR to intrinsic motivation subscales. Most previous studies have shown that ER correlates with IDR at a higher level than with INR (Caleon et al., 2015; Cokley, 2000; Fairchild et al., 2005; Lim \& Chapman, 2015; Osei Akoto, 2014; Smith et al., 2010; Vallerand et al., 1992, 1993; Zhang et al., 2016). According to Fairchild et al. (2005) and Smith et al. (2010), this observation may be a consequence of the fact that the items of ER and IDR primarily focus on future career while the items of INR refer to self-worth and competencies. However, with the sample of the present study, the correlation between ER and INR $(r=.74)$ was stronger than the one between ER and IDR $(r=.68)$. This result was consistent with a number of previous studies (Burgueño et al., 2017; Guay et al., 2015; Orsini et al., 2015), and supported the hypothesis about simplex pattern, though the difference in magnitude between these two correlations was not remarkable.

The correlation between INR and the other subscales also reflected a simplex structure. However, the correlation between INR and IMTA was greater than those between INR and the remaining intrinsic motivation subscales. The reason is possibly that the items of INR and IMTA have contents that focus on selfworth and competencies (Fairchild et al., 2005; Smith et al., 2010). Meanwhile, the IMTK and IMTE have contents that put emphasis on knowledge enrichment.

Previous studies have shown that, compared to IDR, INR has a stronger correlation with intrinsic motivation subscales (Burgueño et al., 2017; Cokley, 2000; Fairchild et al., 2005; Guay et al., 2015; Osei Akoto, 2014). Given these findings, Fairchild et al. (2005) argued that INR might have a higher level of autonomy than IDR. Cokley (2000) also noted that, in comparison to IDR, INR might be closer to the intrinsic motivation types. In contrast with these previous studies and explanations, the results of the current study showed that the correlations between IDR and IMTK, and IMTE were stronger than the correlation between INR and these subscales. However, similar to some previous studies (Orsini et al., 2015; Zhang et al., 2016), the correlation between INR and IMTA was greater than the one between IDR and IMTA. This does not necessarily indicate that the INR has a higher level of autonomy than IDR, but rather because, as shown, INR's items are relatively close to those of IMTA.

The correlation between IDR and external motivation subscales was not significantly different from the correlation between IDR and intrinsic motivation subscales. Furthermore, consistent with previous studies of Orsini et al. (2015) and Caleon et al. (2015), AM correlated with IDR more strongly than with IMTA, and with IMTE, and as approximately strongly as with IMTK. Most studies have shown that the correlation between AM and IDR is strongest (Cokley, 2000; Fairchild et al., 2005; Guay et al., 2015; Smith et al., 2012). These results reflect the view of SDT (Deci \& Ryan, 1985b) that IDR is a highly autonomous form of extrinsic motivation with a compromise between social demands and internal forces.

One interesting point is that the correlations between intrinsic motivation forms were quite strong. This finding is consistent with some previous studies (Burgueño et al., 2017; Caleon et al., 2015; Fairchild et al., 2005; Guay et al., 2015; Osei Akoto, 2014; Smith et al., 2010; Zhang et al., 2016). While Fairchild et al. (2005) commented that this finding confirms the hypothesis that there is no variation in degree of autonomy among intrinsic motivation forms, Cokley et al. (2001) questioned the possibility to discriminate between these types of motivation. Especially in the present study, the correlation between IMTK and IMTE was very strong. The correlation between these two subscales might be greater than the reality because the content of their items refers to positive emotions such as cheerfulness, pleasure, and excitement. In addition, three of the four items of the IMTE 
refer to learning through document reading (Fairchild et al., 2005). Obviously, this activity results in the expansion of knowledge and therefore makes the items of the two scales have the same contents. This could cause the two subscales to correlate quite strongly. In addition, the examination method may also affect the level of correlation between the intrinsic motivation subscales. Specifically, the study of Guay et al. (2015) showed that these subscales were moderately correlated by using ESEM instead of strongly correlated by conducting CFA. The other potential reason may be cultural factor. Osei Akoto's (2014) study comparing American and Ghanaian students showed that the correlations between intrinsic motivation subscales in American students were strong while in Ghanaian students they were average.

Finally, the correlations between the intrinsic motivation subscales and the extrinsic motivation subscales were moderate or strong, similar to the results of some previous studies (Burgueño et al., 2017; Caleon et al., 2015; Guay et al., 2015; Osei Akoto, 2014; Zhang et al., 2016). Zhang et al. (2016) commented that this finding was seldom found in studies conducted with Westerners. Combined with the consideration of means, this result suggests that the learning activities of Asian students are motivated by both social and personal factors. In other words, there is no dominant factor in motivating the learning activities of students. Considering the context of Vietnam, in general, students' undergraduate studies are not only motivated by expectations from family and society, but also driven by the needs and aspirations of the students themselves (Bui, 2009; Dang, 2008; Duong, 2008).

\section{CONCLUSIONS}

The results of this study show that the AMS is a valid and reliable instrument for assessing academic motivation in the context of Vietnam. Theoretically, these results also suggest the application of SDT to psychological and educational studies in Vietnam in the context that we are lacking a fundamental theory for motivation studies. The inclusion of this theory in future studies will open new research directions that are meaningful to Vietnamese students. For example, the influence of satisfaction or frustration of basic psychological needs, of parents' or teachers' autonomy support for the psychological well-being and academic performance of Vietnamese students. The results of these studies can be the basis for building more effective parenting or education methods. In practical terms, future studies can use the AMS to measure students' academic motivation, thereby considering the factors that are the antecedents and consequences of intrinsic and extrinsic motivation.

Despite providing initial evidence of the validity and reliability of the AMS, this study still had some limitations. First, the small size and homogeneity of the research sample reduced the possibility of generalizing the results. Future studies need to be conducted on larger samples with diversity in age, educational level, living area, and socio-economic conditions. Second, the lack of back-translation could reduce the ability to accurately convey the meaning of items. Future research needs to carry out backtranslation to improve the quality of the content of the scale. Third, although CFA has been considered a suitable factorial analysis method in adapting and validating scales, some studies have shown that CFA is more restrictive than ESEM. Later studies may use both CFA and ESEM to compare and improve the results. Fourth, this study only assessed the construct validity. More research is needed to assess the criterion validity of the AMS. Finally, the current study only considered the scale's internal consistency to evaluate the reliability. Therefore, in order to further evaluate the reliability of the scale, future research should consider other indicators, particularly the temporal stability of the subscales.

\section{ACKNOWLEDGEMENTS}

This work was supported by the Faculty of Psychology, University of Social Sciences and Humanities, Vietnam National University. The authors would like to thank Dung Thuy Ninh, Mai Thi Phan, and Thuy Tien Thi La for their help with collecting data, and Egbert Veltman for his help with language editing.

\section{References}

Alivernini, F., \& Lucidi, F. (2008). The Academic Motivation Scale (AMS): Factorial structure, invariance and validity in the Italian context. Testing, Psychometrics, Methodology in Applied Psychology, 15, 211-220.

Alivernini, F., \& Lucidi, F. (2011). Relationship Between Social Context, Self-Efficacy, Motivation, Academic Achievement, and Intention to Drop Out of High School: A Longitudinal Study. The Journal of Educational Research, 104, 241-252. https://doi.org/10.1080/00220671003728062

Anderman, E. M., \& Dawson, H. (2013). Learning with Motivation. In R. Mayer \& P. Alexander (Eds.), Handbook of Research on Learning and Instruction (pp. 219-241). New York: Routledge. https://doi.org/10.4324/9780203839089.ch11

Ardeńska, A., Tomik, R., Berber, S., Düz, B., Çivak, B., Çalişkan, U., \& Ogrodnik, J. (2016). A comparison of physical education students' motivation using polish and turkish versions of the Academic Motivation Scale. Journal of Human Kinetics, 54, 207-218. https://doi.org/10.1515/hukin-2016-0046 
Aydin, S., Yerdelen, S., Gürbüzoğlu Yalmanci, S., \& Göksu, V. (2014). Academic Motivation Scale for learning biology: A scale development study. Education and Science, 39, 425-435. https://doi. org/10.15390/EB.2014.3678

Baker, S. R. (2004). Intrinsic, extrinsic, and amotivational orientations: Their role in university adjustment, stress, well-being, and subsequent academic performance. Current Psychology, 23, 189-202. https://doi.org/10.1007/s12144-004-1019-9

Barkoukis, V., Tsorbatzoudis, H., Grouios, G., \& Sideridis, G. (2008). The assessment of intrinsic and extrinsic motivation and amotivation: Validity and reliability of the Greek version of the Academic Motivation Scale. Assessment in Education: Principles, Policy \& Practice, 15, 39-55. https://doi. org/10.1080/09695940701876128

Bentler, P. M. (1990). Comparative fit indexes in structural models. Psychological Bulletin, 107, 238-246. https://doi.org/10.1037/0033-2909.107.2.238

Beyers, W., \& Goossens, L. (2002). Concurrent and predictive validity of the student adaptation to college questionnaire in a sample of european freshman students. Educational and Psychological Measurement, 62, 527-538. https://doi. org/10.1177/00164402062003009

Bonneville-Roussy, A., Evans, P., Verner-Filion, J., Vallerand, R. J., \& Bouffard, T. (2017). Motivation and coping with the stress of assessment: Gender differences in outcomes for university students. Contemporary Educational Psychology, 48, 28-42. https://doi.org/10.1016/j.cedpsych.2016.08.003

Borsa, J. C., Damásio, B. F., \& Bandeira, D. R. (2012). Adaptação e validação de instrumentos psicológicos entre culturas: algumas considerações [Cross-cultural adaptation and validation of psychological instruments: some considerations]. Paidéia (Ribeirão Preto), 22, 423-432. https://doi. org/10.1590/S0103-863X2012000300014

Brown, T. A. (2015). Confirmatory factor analysis for applied research ( $2^{\text {nd }}$ ed.). New York; London: The Guilford Press.

Bui, H. T. T. (2009). Nghiên cứu so sánh về động cơ học tập của học sinh tiểu học ở Việt Nam và ở Pháp [Comparing primary students' academic motivation between Vietnam and France]. Tap Chí Tâm Lý Học, 11, 23-28.

Bui, H. T. T. (2011). Động cơ học tập theo lí thuyết về sự tự quyết [Academic motivation according to Self-Determination Theory]. Khoa Học Giáo Dục, 66, 44-49.

Bui, H. T. T. (2017). A Self-Determination Theory based motivational model on intentions to drop out of vocational schools in Vietnam. Malaysian Journal of Learning and Instruction, 14, 1-21.

Bullard, J. B. (2016). Academic motivation, learning strategies, and sports anxiety of first-year student-athletes. Journal for the Study of Sports and
Athletes in Education, 10, 99-108. https://doi.org/ 10.1080/19357397.2016.1218646

Burgueño, R., Sicilia, Á., Medina-Casaubon, J., Alcaraz-Ibañez, M., \& Lirola, M.-J. (2017). Revisión de la Escala de Motivación Educativa. Inclusión de la Regulación Integrada para Medir la Motivación en la Formación Inicial del Profesorado [Academic motivation scale revised. Inclusion of integrated regulation to measure motivation in initial teacher education]. Anales de Psicología, 33, 670-679. https://doi.org/10.6018/analesps.33.3.249601

Cain, M. K., Zhang, Z., \& Yuan, K.-H. (2017). Univariate and multivariate skewness and kurtosis for measuring nonnormality: Prevalence, influence and estimation. Behavior Research Methods, 49, 1716-1735. https://doi.org/10.3758/s13428-0160814-1

Caleon, I. S., Wui, M. G. L., Tan, J. P.-L., Chiam, C. L., Soon, T. C., \& King, R. B. (2015). Cross-cultural validation of the Academic Motivation Scale: a singapore investigation. Child Indicators $R^{-}$ search, 8, 925-942. https://doi.org/10.1007/s12187014-9298-7

Can, G. (2015). Turkish Version of the Academic Motivation Scale. Psychological Reports, 116, 388-408. https://doi.org/10.2466/14.08.PR0.116k24w5

Cavusoglu, C., \& Karatas, H. (2015). Academic procrastination of undergraduates: Self-Determination Theory and academic motivation. The Anthropologist, 20, 735-743. https://doi.org/10.1080/ 09720073.2015.11891780

Chong, Y. S., \& Ahmed, P. K. (2012). Understanding student motivation in higher education participation: A psychometric validation of the Academic Motivation Scale in the Malaysian context. International Proceedings of Economics Development and Research, 53, 118-122.

Cokley, K. O. (2000). Examining the validity of the Academic Motivation Scale by comparing scale construction to Self-Determination Theory. Psychological Reports, 86, 560-564. https://doi. org/10.2466/pr0.2000.86.2.560

Cokley, K. O. (2015). A confirmatory factor analysis of the Academic Motivation Scale with black college students. Measurement and Evaluation in Counseling and Development, 48, 124-139. https:// doi.org/10.1177/0748175614563316

Cokley, K. O., Bernard, N., Cunningham, D., \& Motoike, J. (2001). A psychometric investigation of the Academic Motivation Scale using a united states sample. Measurement and Evaluation in Counseling and Development, 34, 109-119.

Conti, R. (2000). College goals: do self-determined and carefully considered goals predict intrinsic motivation, academic performance, and adjustment during the first semester? Social Psychology of Education, 4, 189-211. https://doi. org/10.1023/A:1009607907509 
Dang, T. Q. (2008). Động cơ học tập của học viên ở các trường quân sự [Academic motivation of students of military schools]. Tạp Chí Tâm Lý Học, 8, 27-30.

Dao, H. H. (2008). Đổi mới giáo dục đại học là tiền đề quan trọng để thực hiện mục tiêu 'gắn đào tạo với nhu cầu xã hội’ [Innovation of university education - important prerequiste for achieving the target of 'attaching training to social needs']. Tap Chí Khoa Học và Công Nghệ, Đại Học Đà Nẵng, 5, 135-144.

Davoglio, T. R., Santos, B. S. dos, \& Lettnin, C. da C. (2016). Validação da Escala de Motivação Acadêmica em universitários brasileiros [Validity of academic motivation scale for the Brazilian higher education students]. Ensaio: Avaliação e Políticas Públicas Em Educação, 24, 522-545. https://doi.org/10.1590/S0104-40362016000300002

De Feyter, T., Caers, R., Vigna, C., \& Berings, D. (2012). Unraveling the impact of the Big Five personality traits on academic performance: The moderating and mediating effects of self-efficacy and academic motivation. Learning and Individual Differences, 22, 439-448. https://doi.org/10.1016/j. lindif.2012.03.013

Deci, E. L., \& Ryan, R. M. (1985a). Cognitive evaluation theory. In E. L. Deci \& R. M. Ryan (Eds.), Intrinsic motivation and self-determination in human behavior (pp. 43-85). Boston, MA: Springer US. https://doi.org/10.1007/978-1-4899-2271-7_3

Deci, E. L., \& Ryan, R. M. (1985b). Conceptualizations of Intrinsic Motivation and Self-Determination. In E. L. Deci \& R. M. Ryan (Eds.), Intrinsic motivation and self-determination in human behavior (pp. 11-40). Boston, MA: Springer US. https://doi. org/10.1007/978-1-4899-2271-7_2

Deci, E. L., \& Ryan, R. M. (1985c). Intrinsic motivation and self-determination in human behavior. Boston, MA: Springer US. https://doi.org/10.1007/978-14899-2271-7

Deci, E. L., \& Ryan, R. M. (1985d). Toward an organismic integration theory. In E. L. Deci \& R. M. Ryan (Eds.), Intrinsic motivation and self-determination in human behavior (pp. 113-148). Boston, MA: Springer US. https://doi.org/10.1007/978-1-4899-2271-7_5

Donche, V., De Maeyer, S., Coertjens, L., Van Daal, T., \& Van Petegem, P. (2013). Differential use of learning strategies in first-year higher education: The impact of personality, academic motivation, and teaching strategies. British Journal of Educational Psychology, 83, 238-251. https://doi.org/10.1111/ bjep. 12016

Duong, O. T. K. (2008). Một số nhân tố tác động tới động cơ học tập của sinh viên trường Đại học Bách khoa Hà Nội [Several factors affecting on academic motivation of students of University of Science and Technology in Hanoi]. Tạp Chí Tâm Lý Hoc, 7, 51-57.

Duong, O. T. K. (2013). Một số hướng tiếp cận trong nghiên cứu động cơ học tập [Some approaches in researching on academic motivation]. Tạp Chí Khoa Học Đại Học Sư Phạm Thành Phố Hồ Chí Minh, 48, 138-148.

Elmelid, A., Stickley, A., Lindblad, F., Schwab-Stone, M., Henrich, C. C., \& Ruchkin, V. (2015). Depressive symptoms, anxiety and academic motivation in youth: Do schools and families make a difference? Journal of Adolescence, 45, 174-182. https://doi. org/10.1016/j.adolescence.2015.08.003

Everaert, P., Opdecam, E., \& Maussen, S. (2017). The relationship between motivation, learning approaches, academic performance and time spent. Accounting Education, 26, 78-107. https://doi.org/1 0.1080/09639284.2016.1274911

Fairchild, A. J., Horst, S. J., Finney, S. J., \& Barron, K. E. (2005). Evaluating existing and new validity evidence for the Academic Motivation Scale. Contemporary Educational Psychology, 30, 331-358. https://doi.org/10.1016/j.cedpsych.2004.11.001

Green, J., Liem, G. A. D., Martin, A. J., Colmar, S., Marsh, H. W., \& Mclnerney, D. (2012). Academic motivation, self-concept, engagement, and performance in high school: Key processes from a longitudinal perspective. Journal of Adolescence, 35, 1111-1122. https://doi.org/10.1016/j.adolescence.2012.02.016

Grouzet, F. M. E., Otis, N., \& Pelletier, L. G. (2006). Longitudinal cross-gender factorial invariance of the Academic Motivation Scale. Structural Equation Modeling: A Multidisciplinary Journal, 13, 7398. https://doi.org/10.1207/s15328007sem1301_4

Guay, F., Morin, A. J. S., Litalien, D., Valois, P., \& Vallerand, R. J. (2015). Application of exploratory structural equation modeling to evaluate the Academic Motivation Scale. The Journal of Experimental Education, 83, 51-82. https://doi.org/10.108 $0 / 00220973.2013 .876231$

Haslofça, F., \& Korkmaz, N. H. (2016). Reliability and validity of academic motivation scale for sports high school students'. SHS Web of Conferences, 26. https://doi.org/10.1051/shsconf/20162601104

Hu, L., \& Bentler, P. M. (1999). Cutoff criteria for fit indexes in covariance structure analysis: Conventional criteria versus new alternatives. Structural Equation Modeling: A Multidisciplinary Journal, 6, 1-55. https://doi.org/10.1080/10705519909540118

Karaguven, M. H. U. (2012). The adaptation of Academic Motivation Scale to turkish. Educational Sciences: Theory and Practice, 12, 2611-2618. Retrieved from https://eric.ed.gov/?id=EJ1002866

Khalaila, R. (2015). The relationship between academic self-concept, intrinsic motivation, test anxiety, and academic achievement among nursing students: Mediating and moderating effects. Nurse Education Today, 35, 432-438. https://doi. org/10.1016/j.nedt.2014.11.001

Klassen, R. M., \& Kuzucu, E. (2009). Academic procrastination and motivation of adolescents in Tur- 
key. Educational Psychology, 29, 69-81. https://doi. org/10.1080/01443410802478622

Kusurkar, R. A., Ten Cate, T. J., Vos, C. M. P., Westers, P., \& Croiset, G. (2013). How motivation affects academic performance: a structural equation modelling analysis. Advances in Health Sciences Education, 18, 57-69. https://doi.org/10.1007/s10459-012-9354-3

Lavasani, M. G., Weisani, M., \& Ejei, J. (2011). The role of achievement goals, academic motivation, and learning strategies in statistics anxiety: Testing a causal model. Procedia - Social and Behavioral Sciences, 15, 1881-1886. https://doi.org/10.1016/j. sbspro.2011.04.020

Le, M. V. (2016). Tính hiếu học của người Việt Nam [The studiousness of Vietnamese people]. Tạp Chí Khoa Học Xã Hội Việt Nam, 4, 103-106.

Lee, E. (2005). The relationship of motivation and flow experience to academic procrastination in university students. The Journal of Genetic Psychology, 166, 5-15. https://doi.org/10.3200/GNTP.166.1.5-15

Lim, S. Y., \& Chapman, E. (2015). Adapting the Academic Motivation Scale for use in pre-tertiary mathematics classrooms. Mathematics Education Research Journal, 27, 331-357. https://doi. org/10.1007/s13394-014-0140-9

Liu, W. C., Wang, C. K. J., Kee, Y. H., Koh, C., Lim, B. S. C., \& Chua, L. (2014). College students' motivation and learning strategies profiles and academic achievement: a self-determination theory approach. Educational Psychology, 34, 338353. https://doi.org/10.1080/01443410.2013.785067

Liu, Y. (2015). The longitudinal relationship between Chinese high school students' academic stress and academic motivation. Learning and Individual Differences, 38, 123-126. https://doi.org/10.1016/j. lindif.2015.02.002

Liu, Y., Ferrell, B., Barbera, J., \& Lewis, J. E. (2017). Development and evaluation of a chemistry-specific version of the Academic Motivation Scale (AMS-Chemistry). Chemistry Education Research and Practice, 18, 191-213. https://doi.org/10.1039/ C6RP00200E

Miller, A. K., \& Markman, K. D. (2007). Depression, regulatory focus, and motivation. Personality and Individual Differences, 43, 427-436. https://doi. org/10.1016/j.paid.2006.12.006

Nguyen, Q. T. T. (2017). Một số giải pháp phát triển nguồn nhân lực việt Nam trong thời kì hội nhập quốc tế [Solutions to human resources development in Vietnam in the intergration age]. Journal of Science, Ho Chi Minh University of Education, 14, 171-178.

Orsini, C., Binnie, V., Evans, P., Ledezma, P., Fuentes, F., \& Villegas, M. J. (2015). Psychometric validation of the Academic Motivation Scale in a dental student sample. Journal of Dental Education, 79, 971-981.

Osei Akoto, E. (2014). Cross-cultural factorial validity of the Academic Motivation Scale. Cross Cultural
Management: An International Journal, 21, 104125. https://doi.org/10.1108/CCM-11-2011-0100

Puklek Levpušček, M., \& Podlesek, A. (2017). Veljavnost in zanesljivost Lestvice akademske motivacije na vzorcu slovenskih študentov [Validity and reliability of the Academic Motivation Scale in a sample of Slovenian students]. Psihološka $\mathrm{Ob}$ zorja / Horizons of Psychology, 26, 10-20. https:// doi.org/10.20419/2017.26.461

Ratelle, C. F., Guay, F., Vallerand, R. J., Larose, S., \& Senécal, C. (2007). Autonomous, controlled, and amotivated types of academic motivation: A person-oriented analysis. Journal of Educational Psychology, 99, 734-746. https://doi.org/10.1037/00220663.99.4.734

Reeve, J. (2009). Understanding motivation and emotion (5th ed.). Hoboken, NJ: John Wiley \& Sons.

Renaud-Dubé, A., Guay, F., Talbot, D., Taylor, G., \& Koestner, R. (2015). The relations between implicit intelligence beliefs, autonomous academic motivation, and school persistence intentions: a mediation model. Social Psychology of Education, 18, 255-272. https://doi.org/10.1007/s11218014-9288-0

Rump, M., Esdar, W., \& Wild, E. (2017). Individual differences in the effects of academic motivation on higher education students' intention to drop out. European Journal of Higher Education, 7, 341-355. https://doi.org/10.1080/21568235.2017.1357481

Smith, K. J., Davy, J. A., \& Rosenberg, D. L. (2010). An examination of the validity of the Academic Motivation Scale with a United States business student sample. Psychological Reports, 106, 323-341. https://doi.org/10.2466/pr0.106.2.323-341

Smith, K. J., Davy, J. A., \& Rosenberg, D. L. (2012). An empirical analysis of an alternative configuration of the Academic Motivation Scale. Assessment in Education: Principles, Policy \& Practice, 19, 231250. https://doi.org/10.1080/0969594X.2011.608347

Stover, J. B., de la Iglesia, G., Boubeta, A. R., \& Liporace, M. F. (2012). Academic Motivation Scale: Adaptation and psychometric analyses for high school and college students. Psychology Research and Behavior Management, 5, 71-83. https://doi. org/10.2147/PRBM.S33188

Støen Utvær, B. K., \& Haugan, G. (2016). The Academic Motivation Scale: dimensionality, reliability, and construct validity among vocational students. Nordic Journal of Vocational Education and Training, 6, 17-45. https://doi.org/10.3384/ njvet.2242-458X.166217

Struthers, C. W., Perry, R. P., \& Menec, V. H. (2000). An examination of the relationship among academic stress, coping, motivation, and performance in college. Research in Higher Education, 41, 581-592. https://doi.org/10.1023/A:1007094931292

Thompson, A., \& Gaudreau, P. (2008). From optimism and pessimism to coping: The mediating 
role of academic motivation. International Journal of Stress Management, 15, 269-288. https://doi. org/10.1037/a0012941

Tóth-Király, I., Orosz, G., Dombi, E., Jagodics, B., Farkas, D., \& Amoura, C. (2017). Cross-cultural comparative examination of the Academic Motivation Scale using exploratory structural equation modeling. Personality and Individual Differences, 106, 130-135. https://doi.org/10.1016/j.paid.2016.10.048

Tsorbatzoudis, H., Barkoykis, V., \& Grouios, G. (2001). A preliminary study of the psychometric properties of the academic motivation scale. Psychology: The Journal of the Hellenic Psychological Society, 526-537.

Vallerand, R. J., Blais, M. R., Brière, N. M., \& Pelletier, L. G. (1989). Construction et validation de l'Échelle de Motivation en Éducation (EME). Canadian Journal of Behavioural Science/Revue Canadienne Des Sciences Du Comportement, 21, 323-349. https://doi.org/10.1037/h0079855

Vallerand, R.J., Pelletier, L.G., Blais, M. R., Briere, N. M., Senecal, C., \& Vallieres, E. F. (1992). The Academic Motivation Scale: a measure of intrinsic, extrinsic, and amotivation in education. Educational and Psychological Measurement, 52, 1003-1017. https:// doi.org/10.1177/0013164492052004025

Vallerand, R. J., Pelletier, L. G., Blais, M. R., Briere, N. M., Senecal, C., \& Vallieres, E. F. (1993). On the assessment of intrinsic, extrinsic, and amotivation in education: evidence on the concurrent and construct validity of the Academic Motivation Scale. Educational and Psychological Measurement, 53, 159-172. https://doi.org/10.1177/0013164493053001018

Zhang, B., Li, Y. M., Li, J., Li, Y., \& Zhang, H. (2016). The revision and validation of the Academic Motivation Scale in china. Journal of Psychoeducational Assessment, 34, 15-27. https://doi. org $/ 10.1177 / 0734282915575909 \backslash$ 


\section{APPENDIX}

The Academic Motivation Scale: Vietnamese version

Dưới đây là những câu trả lời cho câu hỏi “Vì sao bạn học đại học?”. Xin vui lòng đọc kỹ và đánh giá mức độ chính xác của mỗi câu đối với bản thân bạn theo thang điểm sau đây:

(Using the scale below, indicate to what extent each of the following items presently corresponds to one of the reasons why you go to college)

\begin{tabular}{cccccc}
$\begin{array}{c}\text { Tuyệt đối } \\
\text { không đúng }\end{array}$ & $\begin{array}{c}\text { Không đúng } \\
\text { một chút }\end{array}$ & Khá đúng & Đúng phần lớn & $\begin{array}{c}\text { Tuyệt đối } \\
\text { đúng }\end{array}$ \\
\hline 1 & 2 & 3 & 4 & 5 & 6
\end{tabular}

\begin{tabular}{|c|c|c|c|c|}
\hline $\begin{array}{l}\text { Does not } \\
\text { correspond } \\
\quad \text { at all }\end{array}$ & $\begin{array}{c}\text { Corresponds } \\
\text { a little }\end{array}$ & $\begin{array}{c}\text { Corresponds } \\
\text { moderately }\end{array}$ & $\begin{array}{c}\text { Corresponds } \\
\text { a lot }\end{array}$ & $\begin{array}{c}\text { Corresponds } \\
\text { exactly }\end{array}$ \\
\hline 1 & 2 & 4 & 5 & 7 \\
\hline
\end{tabular}

\begin{tabular}{lr}
\hline Items & Scale \\
\hline
\end{tabular}

1. Vì tôi không thể tìm được một công việc lương cao chỉ với tấm bằng cấp ba (Because with only a high-school degree I would not find a high-paying job later on)

2. Vì tôi cảm thấy vui vẻ và hài lòng khi học được những điều mới (Because I experience pleasure and satisfaction while learning new things)

3. Vì tôi nghĩ rằng học đại học sẽ giúp tôi chuẩn bị tốt hơn cho công việc mà tôi đã lựa chọn (Because I think that a college education will help me better prepare for the career I have chosen)

4. Vì tôi thích cảm giác vui sướng khi được chia sẻ những ý tưởng và quan điểm của mình với người khác (For the intense feelings I experience when I am communicating my own ideas to others)

5. Thực lòng mà nói thì tôi không biết. Tôi thực sự cảm thấy mình đang bỏ phí thời gian cho việc học đại học (Honestly, I don't know; I really feel that I am wasting my time in school)

6. Vì tôi cảm thấy vui sướng khi tôi có thể vượt lên chính mình đề chinh phục các môn học (For the pleasure I experience while surpassing myself in my studies)

7. Để chứng minh cho chính bản thân tôi thấy rằng mình hoàn toàn có thể học đại học (To prove to myself that I am capable of completing my college degree)

8. Để sau này có thể có một công việc được coi trọng (In order to obtain a more prestigious job later on)

9. Vì tôi cảm thấy hứng thú khi tự mình khám phá ra những điều mới mẻ (For the pleasure I experience when I discover new things never seen before)

10. Bởi vì thực tế học đại học sẽ cho phép tôi bước chân vào ngành nghề mà tôi mong muốn (Because eventually it will enable me to enter the job market in a field that I like)

11. Vì tôi cảm thấy thích thú khi đọc được một tài liệu hay một cuốn sách hay (For the pleasure that I experience when I read interesting authors)

12. Tôi đã từng có những lý do tốt đẹp để học đại học nhưng bây giờ tôi đang băn khoăn không biết có nên tiếp tục hay không (I once had good reasons for going to college; however, now I wonder whether I should continue) 
13. Vì tôi cảm thấy vui sướng khi tôi có thể vượt lên chính mình để đạt được những mục tiêu trong học tập (For the pleasure that I experience while I am surpassing myself in one of my personal accomplishments)

14. Vì khi tôi có thể học tốt ở bậc đại học, tôi cảm thấy bản thân mình có giá trị (Because of the fact that when I succeed in college I feel important)

15. Vì tôi muốn có một cuộc sống ổn định sau này (Because I want to have "the good life" later on)

16. Vì tôi cảm thấy hứng thú khi kiến thức của tôi về những môn học mà tôi yêu thích được mở mang (For the pleasure that I experience in broadening my knowledge about subjects which appeal to me)

17. Vì học đại học sẽ giúp tôi có những quyết định đúng đắn hơn theo định hướng nghề nghiệp mà tôi đã lựa chọn (Because this will help me make a better choice regarding my career orientation)

18. Vì tôi thích cái cảm giác khi bản thân mình bị lôi cuốn vào kiến thức (For the pleasure that I experience when I feel completely absorbed by what certain authors have written)

19. Tôi không thể hiểu vì sao tôi học đại học và thẳng thắn mà nói thì tôi cũng chẳng quan tâm (I can't see why I go to college and frankly, I couldn't care less)

20. Vì sự thỏa mãn khi tôi cảm thấy mình đang trong tiến trình đạt được những mục tiêu học tập khó khăn (For the satisfaction I feel when I am in the process of accomplishing difficult academic activities)

21. Để chứng minh cho chính bản thân tôi thấy rằng mình cũng có năng lực (To show myself that I am an intelligent person)

22. Để có một mức lương tốt hơn sau này (In order to have a better salary later on)

23. Vì tôi muốn được học hỏi về những thứ mà tôi yêu thích (Because my studies allow me to continue to learn about many things that interest me)

24. Vì tôi tin rằng một vài năm học đại học sẽ giúp tôi nâng cao năng lực làm việc (Because I believe that a few additional years of education will improve my competence as a worker)

25. Vì tôi cảm thấy hứng thú khi đọc về những chủ đề mà tôi yêu thích (For the "high" feeling that I experience while reading about various interesting subjects)

26. Tôi không biết và không hiểu mình đang làm gì ở đây nữa (I don't know; I can't understand what I am doing in school)

27. Bởi vì học đại học cho phép tôi được trải nghiệm cái cảm giác thỏa mãn khi tôi đạt thành tích xuất sắc trong các môn học (Because college allows me to experience a personal satisfaction in my quest for excellence in my studies)

28. Bởi vì tôi muốn chứng minh cho chính bản thân tôi thấy rằng mình cũng có thể thành công trong học tập (Because I want to show myself that I can succeed in my studies) 